ACTA UNIVERSITATIS LODZIENSIS

FOLIA LITTERARIA POLONICA 2(40) 2017

http://dx.doi.org/10.18778/1505-9057.40.07

Sławomir Buryła*

\title{
Raport cynika? O życiu i twórczości Andrzeja Brychta
}

Nie będzie jedynie retorycznym zabiegiem pytanie, po co dziś wracać do Andrzeja Brychta? Ci, którzy stwierdzą, że nie warto, odwołać się mogą do argumentów biograficznych. Po co zajmować się takim człowiekiem? Mogą też wskazać na późną, artystycznie słabą prozę: Raport z Monachium, Zmienna ogniskowa, Azyl polityczny, Sandra, Stopa Ikara. Wbrew podobnym opiniom uważam, że trzeba sięgać pod biografię i dzieła Brychta.

\section{„Kaskaderzy” nie dla Brychta}

Dlaczego Brycht nie mógłby trafić do grupy tzw. kaskaderów literatury? ${ }^{1}$ Wszak wielu $\mathrm{z}$,legendarnych i tragicznych” to jego rówieśnicy.

Przyjrzyjmy się najpierw cechom pisarstwa i aspektom życiorysu Brychta, które kazałyby go sytuować w tym gronie.

Pisał dużo i z łatwością - prozę, poezję, reportaż. Jego zamiłowanie do mocnego stylu życia: alkoholu, kobiet, bijatyk, kończących się niekiedy wyrokami więzienia, oraz naturalny talent - bez stosownego wykształcenia akademickiego - czyniły go idealnym reprezentantem środowiska „Współczesności”. Tak jak w niektórych tekstach Edwarda Stachury czy Rafała Wojaczka jest u Brychta przeświadczenie, że ,piękne i prawdziwe jest to tylko, co dzikie, pierwotne, instynktowne, szalone" ${ }^{2}$. W jednym z młodzieńczych opowiadań buńczucznie deklarował swe umiłowanie wolności, chęć pozostania wiernym jedynie sobie: „Nie należę nigdzie ani do nikogo"3.

* Prof. dr hab.; Uniwersytet Warmińsko-Mazurski, Instytut Polonistyki i Logopedii, Zakład Teorii Literatury; 10-725 Olsztyn, ul. Kurta Obitza 1; slawomirburyla@wp.pl.

${ }^{1}$ Zob. Kaskaderzy literatury. O twórczości i legendzie Andrzeja Bursy, Marka Hłaski, Haliny Poświatowskiej, Edwarda Stachury, Ryszarda Milczewskiego-Bruna, Rafała Wojaczka, pod red. E. Kolbusa, słowo wstępne J.Z. Brudnicki, posł. J. Marx, wyd. 2, Wydawnictwo Łódzkie, Łódź 1990.

2 J. Błoński, Brychta ballady podwórzowe, „Twórczość” 1968, nr 1, s. 116-117.

${ }^{3}$ A. Brycht, Paryż z zającem w herbie, w: Opadanie ziemi, Instytut Wydawniczy Pax, Łódź 1962, s. 227. 
Przed śmiercią Brycht spalił niepublikowane maszynopisy, zniszczył materiały zgromadzone na dyskietkach i w pamięci komputera. Jak należy odczytywać ten gest anihilacji? Wszak dokonuje go ktoś, kto stale zabiegał o uznanie, popularność. Czy kryje się w tej decyzji znak totalnego sprzeciwu wobec nowego świata, który już nie chce dawnego buntownika? Trudno orzec. Być może należy ów czyn widzieć jako wypadkową goryczy, rozczarowania i narastającego z czasem poczucia winy (rezultat rachunku sumienia?). Krótki artykuł Zbigniewa Kowalewskiego pt. Zapomnieć Andrzeja Brychta wieńczą zdania sformułowane w trybie moralnego osądu:

Żadnych analiz jego twórczości, nic oprócz grobowej ciszy i milczenia nad tą trumną. To kara za sposób życia i zmarnowany talent. Miłosierdzie nakazuje jednak wybaczenie popełnionych grzechów. Rozstający się ze światem Brycht szczerze za nie żałował. Jeżeli nie na granitowej płycie, to może przynajmniej w pamięci warto wyryć starożytną maksymę Non omnis moriar ..., chociaż Brycht chciał wykasować cały dorobek życia, swoją dumę, żal i wstyd ${ }^{4}$.

Zarówno roztrwoniony talent, jak i nihilistyczny gest artysty, będący kolejną formą destrukcyjnego (autodestrukcyjnego) działania Brychta, łączą go z ,przeklętymi i tragicznymi”. Dzieciństwo i wczesna młodość predestynowały autora $\mathrm{Su}$ chych traw do bycia w kręgu takich twórców. Wywodził się z nizin społecznych. W jego ,edukacji” sporą rolę odegrała ulica. Tu uczył się bić. Nie tylko w tym przypominał Marka Hłaskę. Jego awanturnicza dusza, którą podkreślała postura boksera wagi ciężkiej, spotkała się z duszą artysty. Warto przy tym odnotować, że bohaterowie Brychta niekiedy skrywają pod powłoką twardziela natury wrażliwe. Tak jest u Marka Hłaski, Marka Nowakowskiego czy Ireneusza Iredyńskiego. Tak jest i u Brychta. W Wycieczce Auschwitz-Birkenau narrator zgrywający cwaniaka, chojraka i aroganta w zetknięciu z rzeczywistością obozu okazuje się zakompleksionym inteligentem, w którym świat lagru obnaża udawaną nieczułośćs

Autor Balbiny - tak jak XIX- i XX-wieczni poeci przeklęci - do swoich opowiadań wprowadzał często przedstawicieli lumpenproletariatu, złodziei, drobnych rzezimieszków, przestępców, ludzi z tzw. marginesu społecznego. Nie to jednak przysporzyło mu etykiety prowokatora, nie to sprawiało, że otaczał go nimb ciekawości i zainteresowania. Odbiorców bulwersowało utożsamianie się narratora (autora) z wykreowanymi postaciami. Jak zauważała Alicja Lisiecka, istota tej niebezpiecznej taktyki nie tkwiła w epatowaniu pornograficznymi obrazami, dobrze znanymi z dzieł przedstawicieli pokolenia '56:

${ }^{4}$ Z. Kowalewski, Zapomnieć Andrzeja Brychta, Wiadomości 24 pl, http://www.wiadomosci24.pl/artykul/zapomniec_andrzeja_brychta_67650.html [dostęp: 9.09.2016].

${ }^{5}$ Zob. M. Orski, Etos lumpa. Szkice literackie, Zakład Narodowy im. Ossolińskich, Wrocław 1978, s. 23. 
Rzecz w tym, że zarówno Iredyński, jak i Nowakowski czy Brycht, w pewnym też stopniu Mikołajek i Czycz, solidaryzują się pozersko ze swoimi knajackimi bohaterami, z bandą lumpów, waluciarzy, rzezimieszków i pijaków, zboczeńców i sadystów, którzy wypełniają karty ich książek ${ }^{6}$.

Już w latach 60. Jan Błoński - inaczej niż Lisiecka - dowodził, że w postawie Brychta jest wiele ze starannie przemyślanej pozy. Kryje się pod nią „literacka filozofia"'.

Brycht wkładał niemało wysiłku w zbudowanie wokół siebie atmosfery artysty kontrowersyjnego. Czynił to między innymi w trakcie wieczorów autorskich. Konstruował wtedy „wizerunek pisarza-buntownika, przeciwstawiającego się całemu światu, który nie liczy się z żadnymi konwenansami, silnego mężczyzny, który pod wpływem doznanych krzywd musi ukryć głęboko delikatność i wrażliwość"s. Wspierał go niekiedy opowieściami o bójkach i awanturach. Ideałem był silny fizycznie i psychicznie mężczyzna, doświadczony przez życie, odważny i pewny siebie, taki, co nie tchórzy i nie poddaje się trudnościom losu. Marek Nowakowski wspominał: „Opowiadaliśmy zdarzenia z własnych przeżyć, potęgowaliśmy drastyczność. Kreowaliśmy się na twardzieli, doświadczonych charakterniaków. Brycht uwielbiał eksponować swoje przewagi fizyczne. Duży, silny. Bił się, nie pękał"'.

Portret buntownika, outsidera musiał być nader ważny dla Brychta, skoro pozostał mu wierny nawet w latach kontaktów ze Służbą Bezpieczeństwa i słanych do niej donosów. Sięgnijmy do ustaleń Andrzeja Chojnowskiego:

Prowadząc skrycie drugie życie u boku Służby Bezpieczeństwa, starał się ocalić swój wizerunek „młodego gniewnego”, a w trakcie wystąpień publicznych prezentował w dalszym ciągu spektakl, będący mieszaniną cynizmu, kokieterii, samochwalstwa oraz niekontrolowanych odruchów niechęci wobec świata, w którym przyszło mu żyć ${ }^{10}$.

Jeśli jednak jakąś cechę kaskaderów literatury Brycht ucieleśniał w stopniu pełnym, to właśnie bunt wyrażający się w łamaniu schematów obyczajowych, w pijackich rozróbach, knajackiej mentalności i stylu życia. Jedyna wątpliwość, jaka się tu rodzi, to pytanie, na ile te zachowania pisarza były wystudiowane i przemyślane, a na ile stanowiły przejaw jego nieposkromionego ducha. Najprawdopodobniej były funkcją obydwu tych czynników. Zapewne z czasem

${ }^{6}$ A. Lisiecka, Seks, anarchia, literatura, w: Prognoza pogody, Czytelnik, Warszawa 1966, s. 94.

${ }^{7}$ Zob. J. Błoński, dz. cyt., s. 115-116.

${ }^{8}$ A. Chojnowski, Sceny ukryte z życia pisarza. Tajemnice Andrzeja Brychta, „Dzieje Najnowsze" 2008, nr 3, s. 119.

${ }^{9}$ M. Nowakowski, Pióro. Autobiografia literacka, Wydawnictwo Iskry, Warszawa 2012, s. 40.

${ }^{10}$ A. Chojnowski, dz. cyt., s. 129-130. 
Brycht uznał swą buńczuczną naturę za ważną część strategii marketingowej. Z pewnością nie miał on nic ze straceńczej, igrającej z życiem duszy Stachury czy Wojaczka. Poeci przeklęci umierali młodo i tragicznie. Wczesna, tragiczna śmierć dawała solidne podwaliny pod legendę. I była przepustką do niej. W przeciwieństwie jednak do Stachury i Wojaczka autor Opadania ziemi był piewcą życia, nie interesowały go zabawy ze śmiercią. Szaleństwo u Brychta miało swoje granice. Wyznaczała je odkryta na łódzkiej ulicy oraz w aresztach i więzieniach prawda, że o życie trzeba walczyć. Samobójstwo jest przejawem słabości, „frajerstwa", a nie męskiej siły i determinacji - wartości i postaw, które starał się uosabiać Brycht i jego bohaterowie.

Jan Z. Brudnicki w Stowie wstępnym do Kaskaderów literatury tak charakteryzował „artystów przeklętych”: „Tylko życie mocne, oszałamiające, rozpędzone aż do szaleństwa - daje prawo do bycia poetą. I to pod warunkiem, że pisze się całym [podkr. autora - J.Z.B.] sobą, że nie ma żadnego przedziału pomiędzy sztuką i życiem, bo są to tylko dwie strony tej samej indywidualności" ${ }^{\prime 1}$. Nie jest to przypadek Brychta. Ten bowiem dobrze wiedział nie tylko, jak rozdzielić życie od sztuki, ale i jak ze sztuki uczynić źródło intratnych zarobków.

W przypadku twórcy Raportu z Monachium na przeszkodzie przed zakwalifikowaniem go jako „przeklętego i tragicznego” staje również jego konformistyczna postawa z połowy lat 60 . Chodzi o współpracę ze Służbą Bezpieczeństwa. Brycht przyjął pseudonim operacyjny „Gerard”. Rozpracowywał głównie środowiska zagranicznych dziennikarzy i artystów, ale też donosił na kolegów po piórze (np. na Nowakowskiego) ${ }^{12}$.

Razem z Brychtem na ścieżki pisarskiej kariery wkraczał Nowakowski. Przez pewien czas byli sobie bliscy. Autor Silnej goraczki przywołuje postać kolegi w Dzienniku podróży do przeszłości oraz w Piórze. W obydwu portretach dojrzymy te same komponenty: „Cenił nade wszystko w swojej wizji szansę dużych pieniędzy, pławił się w rojeniach o luksusowych hotelach, wystawnych kolacjach z pięknymi damami, wyścigowych samochodach i podróżach. [...] Zalatywało to kiczem, tandetą"13. Nieco dalej Nowakowski wskazuje na konsekwencje takiej postawy, mówiąc, że „pragnienie pisarskiej sławy było niebezpiecznie bliskie uzależnienia się od rządzących"'14. Ceniący luksus i pieniądze Brycht - od połowy lat 60 .

${ }^{11}$ J.Z. Brudnicki, Stowo wstęne do: Kaskaderzy literatury, s. 7.

${ }^{12} \mathrm{Na}$ temat współpracy Brychta ze służbami specjalnymi PRL zob. A. Chojnowski, dz. cyt., s. 125. W świetle ustaleń Chojnowskiego nie można jednoznacznie przesądzić o charakterze tej współpracy. Chojnowski mówi o nawet o grze z SB, jaką w pewnym momencie podjął Brycht, choć jednocześnie nikt nie może kwestionować samej współpracy, jak też licznych donosów słanych na ludzi ze środowiska. Badacz nie rozstrzyga ostatecznie o genezie tej współpracy. Najprawdopodobniej znaczną rolę odegrała tu chęć wyjazdu na Zachód.

${ }^{13}$ M. Nowakowski, Pióro..., s. 54.

${ }^{14}$ Tamże, s. 55. A przecież sądy takie nie są odosobnione. Zob. wypowiedzi uczestników filmu dokumentalnego Errata do biografii: Andrzej Brycht, reż. Z. Kowalewski, A. Gruziel, TVP 2008. 
- był zarazem po stronie systemu. Konszachty z władzą zapewniały wysokie tantiemy, zamówienia i intratne propozycje artystyczne. Inaczej zatem niż Hłasko, Iredyński, Stachura, Milczewski Bruno, a późnej Wojaczek - wielcy niepokorni, buntownicy i przeklęci - Brycht śnił o egzystencji peerelowskiego burżuja.

Marzenia o bogactwie ucieleśniały zachodnie markowe samochody, uznanie społeczne oraz powodzenie u kobiet. „Wielkopańskie zachcianki” mogły być pochodną biedy, jakiej Brycht zaznał w dzieciństwie - trudnym do wyrugowania wspomnieniem łódzkich Bałut i Widzewa. Pamięć o tym była w pisarzu zakodowana bardzo głęboko. Mogła stanowić rodzaj wewnętrznego imperatywu, by już nigdy nie dać się sprowadzić do roli człowieka „drugiej kategorii”.

W pewnym momencie lumpenproletariackie korzenie stają się dla Brychta nie źródłem kompleksów, lecz obszarem psychologicznej rozgrywki. Chojnowski, pracując na materiałach Służby Bezpieczeństwa, odnotuje, że Brycht na spotkaniach autorskich często drwił z prowincjusza, z jego zaściankowości. Z wyższością spoglądał na przedstawicieli środowisk, o których mówił w swoich tekstach - które znał i z których się wywodził1 ${ }^{15}$. Niewykluczone jednak, że i tego typu postawa mogła być częściowo udawana, kreowana na potrzeby wizerunku artysty.

Nieposkromiona dusza Brychta - niekiedy szalona, dziecięco przekorna i niepoukładana - stała się zapewne jednym ze źródeł problemów, jakie miał artysta. Być może po prostu był niedojrzały - to znaczy nie pojmował w pełni wagi wypowiadanych słów, podejmowanych decyzji, bagatelizował je, zbywał przed samym sobą, przyjmując postawę bawiącego się chłopca, wchodzącego w różne role społeczne, nakładającego kolejne maski tylko po to, by je wypróbowywać, by odegrać przypisane im role. Zarazem trudno nie dostrzec, że od pewnego momentu autor Balbiny stawał się (a raczej bywał) człowiekiem cynicznym; wypalonym, zgnuśniałym, dla którego drogowskazy moralne są zbyteczną przeszkodą albo anachronicznym przesądem - odpowiednim dla jednostek słabych i tchórzliwych. Współpracy z SB - jej formy i genezy - nie można bowiem wyjaśnić infantylizmem i młodzieńczą dezynwolturą ${ }^{16}$.

\section{Raport cynika?}

Brycht nie mógł pominąc tematyki wojennej. Poniekąd był na nią skazany. Jak powtarzał - czym potem tłumaczył między innymi antyniemiecki charakter Raportu z Monachium - był wojennym półsierotą: śmierć ojca stanowiła doniosły

${ }^{15}$ Zob. A. Chojnowski, dz. cyt., s. 120.

${ }^{16} \mathrm{Na}$ ile prawdziwa jest sugestia mówiąca, iż pisarz zdecydował się opuścić kraj, gdy skończył się protektorat ludzi od Mieczysława Moczara, niełatwo orzec. W Stowach z chaosu Brycht odcina się od jakiejkolwiek znajomości z szefem Ministerstwa Sprawa Wewnętrznych. Te deklaracje nie muszą być jednak prawdziwe. 
komponent w jego artystycznej biografii. Sprawa z Niemcami była sprawą osobistą i szczególną. Także przez fakt pochodzenia i korzeni rodzinnych ${ }^{17}$.

Motyw wojny u Brychta przywołuje się zwykle w kontekście Raportu z Monachium, Dancingu w kwaterze Hitlera i Wycieczki Auschwitz-Birkenau. To niesprawiedliwe uproszczenie. „Czasów pogardy” dotykają wszak już opowiadania i nowele z Opadania ziemi oraz Ulicy Pomarańczowej. Dotykają w sposób oryginalny, wyrazisty, zapadający w pamięć. Obraz okupacji stanowi jeden z wiodących wątków w Opadaniu ziemi i Ulicy Pomarańczowej. W Zbrodniarzach (Opadanie ziemi) spotyka się z prymarnym dla Brychta tematem więziennym; w Matej prozie przed snem (Opadanie ziemi) z pytaniem o pokolenie naznaczone swądem krematoryjnego dymu. Bialy korytarz (Ulica Pomarańczowa) podnosi znane i często dyskutowane zagadnienie dylematów moralnych, jakie rodzi wojna. Jest to również ciekawy utwór dla tropicieli związków między męskością i wojną. Notabene męskość - jej kulturowe wzorce oraz implikacje - jedno z kluczowych zagadnień dla prozy Brychta jest konsekwentnie pomijane przez badaczy.

Zajmiemy się teraz trzema utworami, którym można postawić zarzut o służalczość wobec peerelowskiej władzy oraz prowadzonej przez nią polityki historycznej: Dancingiem w kwaterze Hitlera, Wycieczka Auschwitz-Birkenau oraz Raportem z Monachium. Od razu wszakże odnotujmy wyjątkowy status Raportu $z$ Monachium na tle dwóch pozostałych tekstów.

Najbardziej zjadliwą recenzję Raportu z Monachium opublikował Tadeusz Nowakowski. Znakomity dziennikarz, publicysta i znawca tematyki niemieckiej, dziełu Brychta odmówił jakiekolwiek wartości. W ujęciu Nowakowskiego $R a$ port z Monachium stanowi

wręcz klasyczny przykład dla uczniów szkół dziennikarskich, jak nie [podkr. autora - T.N.] należy pisywać reportaży. Bo czyż można nazwać reportażem niedbały zlepek dezinformacji, mitomańskich przywidzeń, majaczeń, sztubackich żartów, przekręconych plotek, pomówień, ćwierć-pół i całych nieprawd, a nawet - trudno nie użyć tego słowa - nieuczciwości? ${ }^{18}$

${ }^{17}$ Sprawa śmierci i pochodzenia ojca nie jest jasna. Henryk Dasko - pozostawiając czytelnika w kręgu pytań i wątpliwości - pisze tak: ,Jego ojciec Eugeniusz, z zawodu przedsiębiorca-meblarz, nie wrócił z wojny. Brycht podawał rozmaite, czasami sprzeczne ze sobą wersje losów ojca: wedle Raportu z Monachium miał się znaleźć w obozie jenieckim na zachodzie Niemiec już we wrześniu 1939 roku, wedle innej, opowiadanej prywatnie historii - wywieziono go na roboty z łapanki ulicznej w 1941 roku. Śmierć ojca również nie jest w pełni wyjaśniona. Brycht pisał, że ojciec został zastrzelony przy próbie ucieczki ze stalagu w Lotaryngii w lipcu 1944 roku. Rodziny ojca i matki Brychta były po części pochodzenia niemieckiego, co dało początek uporczywie krążącym w latach sześćdziesiątych pogłoskom, że ojciec Brychta zginął jako żołnierz Wehrmachtu”. H. Dasko, Brycht, w: Odlot malowanego ptaka, oprac. M. Komar, Rosner i Wspólnicy, Warszawa 2009, s. 22.

18 T. Nowakowski, Manneken-pis, „Kultura” 1967, nr 6, s. 133-134. 
Zarzucając Brychtowi nieudolności gatunkowe, kwalifikował Raport z Monachium jako przejaw ,ciemnogrodzkiego bełkotu i frazesu hurra-nacjonalistycznego, tak modnego ostatnio w Uzbekistanie [...]"19.

Czy obraz wojny, relacji polsko-niemieckich w reportażu Brychta - jak sugeruje Nowakowski - to tylko cyniczne kłamstwo obliczone na poklask i profity finansowe w kraju? Wbrew pierwszemu odruchowi odpowiedź na tę kwestię nie jest łatwa. Nie podlega dyskusji, iż w spojrzeniu Brychta na wojnę - poza aspektem materialnym - istniał czynnik niemerkantylny. Jedno wszakże nie budzi wątpliwości, mniej więcej od Raportu z Monachium tak ceniona przez Brychta autentyczność i niezależność traci na sile i znaczeniu. Po Raporcie z Monachium powstają kolejne utwory, w których cynizm trudno odróżnić od obsesji ideologicznych, goryczy, żółci i presji resentymentów ${ }^{20}$.

Niezależnie od tego, jak bardzo Brycht zaangażował się we współpracę z peerelowskimi służbami specjalnymi, od roku 1966 zmienia się jego stosunek do władzy. Z butnego, niepokornego pisarza wypowiadającego na spotkaniach z czytelnikami treści nieakceptowane przez partię, staje się wobec niej uległym, a jego wypowiedzi oraz opowiadania wykazują zadziwiającą zbieżność z linią propagandową komunistów. Henryk Dasko przywołuje tamten czas w słowach:

Dla partii artysta kalibru Brychta, skłonny oddać pióro w służbę reżimu, stanowił skarb. Nie zdarzało się, aby twórca popularny i utalentowany, niemal jednogłośnie oklaskiwany prze krytyków, a do tego publicznie prezentujący profil kontestatora, z własnej woli wyrażał to, co władza chciała wmówić społeczeństwu: niemiecki militaryzm, żądza odwetu, chęć zagarnięcia Ziem Zachodnich ${ }^{21}$.

Jeśli nawet nie jest w tej uległości wobec komunistów konsekwentny, to z pewnością jego buńczuczna postawa wobec nich już nie przypomina tej z końca lat 50. i pierwszej połowy następnej dekady.

Przywołajmy dwa argumenty - jeden biograficzny, wynikający z temperamentu artysty, drugi literacki, wyprowadzony ze wspomnianych tekstów Brychta. Zarówno racje ze sfery biograficznej, jak i literackiej osłabiają tezę o absolutnym wyrachowaniu i pragmatyzmie pisarza.

Jako wątpliwe należy uznać uwagi pod adresem Dancingu w kwaterze Hitlera oraz Wycieczki Auschwitz-Birkenau, widzące w nich jedynie przykład akceptacji dla polityki Mieczysława Moczara i Bolesława Piaseckiego. Z pewnością krytyka Zachodu, zachodniego konsumpcjonizmu (tamtejszego stylu życia,

\footnotetext{
${ }^{19}$ Tamże, s. 133.

20 Taka jest też geneza - późniejszego od Zmiennej ogniskowej-Azylu politycznego.

${ }^{21}$ H. Dasko, dz. cyt., s. 45.
} 
sytemu wartości), wspierała stanowisko komunistów ${ }^{22}$. Do pewnego stopnia mogła być ona odczytywana jako wyraz aprobaty dla silnie zaznaczających się w latach 60. tendencji nacjonalistycznych, dla mocno akcentowanych na różnych polach sztuki, edukacji i wychowania koncepcji patriotyzmu wojskowego ${ }^{23}$. Opowiadań tych - ani ich genezy - nie można jednak sprowadzać tylko do tego wymiaru. Wyrażają one bowiem również autentyczne poglądy Brychta.

Omawiając Wycieczkę Auschwitz-Birkenau oraz jej filmową wersję Wyciecz$k a w$ nieznane (w reżyserii Jerzego Ziarnika), Tomasz Łysak słusznie zauważa, iż w obydwu przypadkach

pożądanym efektem zetknięcia się z obozem nie jest zdobycie wiedzy opartej na intelektualnym dystansie, lecz zanurzenie się w otchłań horroru. Innymi słowy, bohater potrzebuje prawdy przeżycia, próbując wypełnić lukę dzielącą go od wydarzeń z przeszłości ${ }^{24}$.

Emocje zatem kierują myślami autora. Logika emocji rządzi jego wyborami i preferencjami ideowymi. Ona też daje o sobie znać, gdy zderzają się ze sobą dwa style życia: nowoczesny - hedonistyczny, zrywający z moralizatorstwem - oraz cierpiętniczy, uwikłany w przeszłośćc ${ }^{25}$. Odrzucając wizję świata młodych ludzi odcinających się od tego, co przyniosły dzieje hitlerowskiego terroru, Brycht nie ma złudzeń, że przeszłość (choćby najbardziej okrutna) musi przegrać w rywalizacji z chwilą obecną ${ }^{26}$. Nie idzie jednak za tym konstatacja: to, co było, należy odstawić do lamusa i zająć się problemami teraźniejszości. Notabene w Dancingu w kwaterze Hitlera negatywnie przedstawiani są również kombatanci - ci z nich, którzy kupczą przeszłością.

Brycht nie liczy na poklask ani rówieśników, ani peerelowskich dygnitarzy. Mówi szczerze, zadziornie. Jest w narratorze Dancingu w kwaterze Hitlera wiele pretensji do bananowej młodzieży, jej indolencji wobec przeszłości, jej kosmopolitycznego zapatrzenia i wartości wyrastających z kultury Zachodu ${ }^{27}$. Nie można

${ }^{22}$ Oceny cywilizacji europejskiej naznaczonej wojną dokonuje Brycht we wczesnym tekście pt. Paryż z zajacem w herbie (Opadanie ziemi). Udaje mu się spoić harmonijnie temat outsidera, niedopasowanego do wymogów zachodniego świata wyrzutka, z rachitycznym namysłem nad cywilizacją europejską dotkniętą Katastrofą.

${ }^{23}$ Zob. Ł. Polniak, Patriotyzm wojskowy w PRL w latach 1956-1970, Wydawnictwo Trio, Warszawa 2011. Zob. też M. Zaremba, Komunizm, legitymizacja, nacjonalizm. Nacjonalistyczna legitymizacja władzy komunistycznej w Polsce, Wydawnictwo Trio, Warszawa 2001.

${ }^{24}$ T. Łysak, Jakiej historii potrzeba? Tematyka obozowa w zapomnianych tekstach Andrzeja Brychta i Tadeusza Hołuja, „Kwartalnik Filmowy” 2012, nr 77/78, s. 172.

25 Tamże, s. 179.

${ }^{26}$ Tamże, s. 180.

${ }^{27}$ Pierwszą, krótszą wersję tego opowiadania, zatytułowaną Dansing, Brycht zamieścił w Ulicy Pomarańczowej. 
bowiem „żyć na tej ziemi, nie znając jej przeszłości”28. Oto sens ataku autora Ulicy Pomarańczowej. Jak przekonuje Tadeusz Drewnowski: „Brycht jest pisarzem tego pokolenia i przedstawia je od środka, od wewnątrz, w najrozmaitszych odmianach"29. Jest rejestratorem jego pragnień, miraży i klęsk. Zarazem Brycht lubiący wystawne życie zawsze stawia siebie poza środowiskiem złotej młodzieży doby PRL. To przecież z jej ideałami rozprawia się w Dancingu w kwaterze Hitlera.

Drewnowski słusznie zestawiał Dancing $w$ kwaterze Hitlera $\mathrm{z}$ opowiadaniami Borowskiego. W jednym i w drugim przypadku bowiem chodzi o te same „drapieżne, nabrzmiałe pasje, podobnie jątrzące i prowokujące moralnie” ${ }^{30}$. O nieufność wobec wytartych frazesów i sloganów o historii. Tu między innymi biegnie linia podziału między przedstawicielami starszej i młodszej generacji.

Jak wspomniano poglądy Brychta współgrały z antyinteligenckim, narodowym (czyli przede wszystkim antyniemieckim) nurtem reprezentowanym przez ekipę rządową Władysława Gomułki. Powodzenie jednak, jakim cieszyły się Dancing $w$ kwaterze Hitlera oraz Raport z Monachium, nie mogło być jedynie wynikiem działań propagandowych. Niechęć, podejrzliwość i wrogość wobec Niemiec i Niemców - będące wyznacznikiem polityki Gomułki - znajdowały potwierdzenie nie tylko w niekłamanej idiosynkrazji pisarza. Obsesje antyniemieckie władzy i Brychta korespondowały również z nastrojami ciągle żywymi w ówczesnym społeczeństwie.

Krytyczna ocena obrazu wojny i społeczeństwa niemieckiego w Raporcie z Monachium nie kwestionuje zaangażowania, sugestywności stylu wyróżniającego książkę Brychta. O postawie autora Suchych traw przenikliwie mówił Wilhelm Szewczyk - jeden z partyjnych znawców tematyki niemieckiej w dobie PRL. Zarzucając Brychtowi uproszczenia w widzeniu ruchu młodzieżowego w Niemczech, Szewczyk stwierdzał:

Z drugiej jednak strony - gdyby rzeczywiście Brycht przestudiował to lub inne zagadnienie, to znaczy gdyby obłożył się mądrymi książkami o Niemczech współczesnych (bo i takie przecież ukazały się u nas) i próbował porównywać swoje obserwacje z umotywowanymi poglądami innych obserwatorów, szczególnie naukowców,

${ }^{28}$ T. Drewnowski, Prowokacje na czasie, w: Krytyka i giełda. Szkice literackie, Warszawa 1969, s. 296.

${ }^{29}$ Tamże, s. 293.

30 Tamże, s. 289. Borowski - jako kojarzony z tendencjami demitologizującymi w literaturze - stał się jednym z patronów tych właśnie tendencji w młodej polskiej prozie po roku 1956 i na początku kolejnej dekady. W paryskiej „Kulturze” Jerzy R. Krzyżanowski konstatował: „Nie ulega wątpliwości, że cała grupa najmłodszych polskich prozaików i poetów [...] wywodzi się z pisarstwa Tadeusza Borowskiego”. J.R. Krzyżanowski, O pisarstwie Andrzeja Brychta, „Kultura” 1967, nr 3, s. 136. 
książka jego straciłaby najważniejszy swój walor, mianowicie świeżość, mianowicie cierpkość i pasję, zaangażowanie tak bolesne, że aż miejscami wydaje się zanadto literackie ${ }^{31}$.

Cynik raczej nie angażowałby się tak bardzo. Nie zadałby sobie tyle trudu, aby maksymalnie zsubiektywizować opowieść, tak emocjonalnie ją nasycić. Mógł to uczynić ktoś, kto miał wyraźnie zdeklarowane przekonania. Nie przeczy to jednak temu, że dostrzegając ich zbieżność z działaniami władzy, mógł swoje poglądy wykorzystać dla zdobycia „forsy” - jak zwykł mawiać twórca Balbiny; nie neguje też zasadności pytania o genezę Raportu z Monachium w kontekście związków ze Służbą Bezpieczeństwa.

W swoich notatkach dziennikowych Jerzy Andrzejewski dobrze oddaje to, o co nam chodzi, mówiąc o artystycznej kondycji Brychta jako autora Reportu z Monachium:

W nowym numerze „Kultury” pierwszy odcinek reportażu Brychta z Wietnamu. Niestety, nawet w stosunku do reportaży niemieckich, wrednych, lecz świetnie napisanych - daleko posunięty rozkład pisarski. Przypuszczałem, że Brycht po wszystkim złem, jakie wyrządził sobie i za cenę niewartą jego wielkiego talentu, przewróci się na pierwszym opowiadaniu, ponieważ jako pisarz z prawdziwego zdarzenia nie będzie mógł pisać równie swobodnie i niezależnie, jak to czynił przed swoją podróżą do RFN. Przewrócił się wcześniej. Jego brutalność zmieniła się w bezsilne miotanie wyzwisk, ostrość widzenia - w liryczny patos, żałosne popłuczyny po najgorszej Młodej Polsce [podkr. moje - S.B.] ${ }^{32}$.

Brycht nie umiał pisać na zamówienie. Nawet jednak wtedy tliła się jeszcze reszta talentu w jego stylu.

Przywołajmy jeszcze Piotra Kuncewicza, który daje taką oto charakterystykę całego dorobku Brychta:

$\mathrm{Na}$ dodatek został [...] [on] tknięty nieuleczalną pasją oskarżycielską, a jak już raz zacznie, wali na oślep, chociaż nigdy nie są to konwulsyjne działania buntownika: bije tych, których nie lubi „zwyczajny człowiek” i władza. Dostaje się więc niewiernym kobietom, Żydom, waluciarzom, pedałom, inteligentom, prostytutkom, Niemcom, bananowej młodzieży, emigrantom, literaturom a wreszcie i Kościołowi. Słowem, komplet fobii okresu „późnego Gomułki”33.

${ }^{31}$ W. Szewczyk, Podróż w kręgi piekielne, „Miesięcznik Literacki” 1968, nr 2, s. 115.

32 J. Andrzejewski, Notatki szpitalne, w: Apelacja, Czytelnik, Warszawa 1983, s. 130.

${ }^{33}$ P. Kuncewicz, Agonia i nadzieja, t. 4: Proza polska od 1956, Polska Oficyna Wydawnicza „BGW”, Graf-Punkt, Warszawa 1994, s. 20. 
I dalej puentuje Kuncewicz: „Jeśli by się tu szukało jakiegoś programu, to pewnie byłby to postulat «oczyszczenia» społeczeństwa z tych wszystkich, co wątpliwi, nieentuzjastyczni, niedostatecznie prości, prawi i przaśni” ${ }^{34}$. Sądy te wszakże odnoszą się głównie do Brychta z czasów Raportu z Monachium oraz Opowieści z tranzytu, Sandry i Azylu politycznego.

Krytyczny wobec brychtowskiej ,,pogoni za forsą", alkoholem i dziewczynami, Nowakowski tak oto mówił o istocie łączącej ich więzi:

Obaj byliśmy pyszałkowaci. Uważaliśmy nieskromnie, że w odróżnieniu od innych początkujących kolegów mamy swój kamień filozoficzny pisania, odkrywamy prawdę o ludziach z samego dna, być może prymitywnych, ale elementarnie wartościowych, trzymających się swego kodeksu. [...] A wszyscy inni to mięczaki, glina do ugniatania. Pogardzaliśmy tym gorszym ludzkim gatunkiem. Także kolegów po piórze mieliśmy za inteligencików, teoretyków bez pojęcia o prawdziwym życiu. Frajerami oni byli dla nas, często ich ośmieszaliśmy i straszyliśmy swym rzekomym zbójeckim usposobieniem ${ }^{35}$.

Kamieniem filozoficznym Brychta, którym dysponował w Suchych trawach, Opadaniu ziemi i Ulicy Pomarańczowej, był autentyzm - kategoria tak chętnie eksplorowana w tekstach oraz biografiach przedstawicieli generacji ' 56.

Tam, gdzie Brycht przekracza próg prawdy jednostkowego przeżycia i wchodzi na teren uogólnienia, tam traci swe atuty. Staje się niewiarygodny. Ujawniają to choćby Opowieści z tranzytu. Twórca Suchych traw, kiedy ma się zdobyć na refleksję historiozoficzną, psychologiczną, której ramy nie byłyby tylko ramami pojedynczego doświadczenia, przedzierzga się $\mathrm{w}$ taniego moralizatora albo w prowokatora. Widać wyraźnie, że intelektualna poza, która go razem z Nowakowskim odstręczała od kolegów po piórze, nie na darmo wywoływała u dwóch ,naturszczyków” tak wiele emocji. O ile jednak Nowakowski nie próbował intelektualizować, a w każdym razie nie w opowiadaniach, o tyle Brychtowi z czasem takie passusy pseudointelektualne zdarzały się coraz częściej, by w końcu osiągnąć punkt kulminacyjny w spiskowych teoriach forsowanych najpierw w Zmiennej ogniskowej, a potem w Sandrze i Azylu politycznym.

\footnotetext{
${ }^{34}$ Tamże, s. 20-21.

${ }^{35}$ M. Nowakowski, Pióro..., s. 41.
} 


\section{Obłęd „autentyczny”}

W 1986 roku w tomie Opowieści z tranzytu ukazuje się w Zmienna ogniskowa. Przywołuję ten utwór dlatego, by na jego przykładzie wskazać, jak właściwe Brychtowi ostrze krytyki, duch buntu oraz potrzeba konfrontacji z powszechnie uznanymi prawdami i wyobrażeniami zaprowadziły go na manowce.

Zmienna ogniskowa dowodzi artystycznej klęski zrodzonej z żądzy niszczenia. Brycht bowiem tylko pozornie tropi ukrytą prawdę o lagrze, próbując uderzyć w „zmowę milczenia”. Nie jest to opowiadanie o nazistowskich obozach, mimo iż traktuje o nich znaczna część fabuły. Brycht wcale nie zamierza szukać nowej formuły do mówienia o Auschwitz kosztem naruszenia społecznego tabu (w tym przypadku tajemnicy śmierci franciszkańskiego zakonnika). Nie jest to więc strategia Borowskiego. Byliśmy w Oświęcimiu i Pożegnanie $z$ Maria - chociaż zrodzone $\mathrm{z}$ ducha protestu - nie udają się w ,podróż do kresu nocy" jedynie z myślą o zszokowaniu czytelnika. U końca drogi wyznaczonej przez Byliśmy w Oświęcimiu i Pożegnania z Maria nie znajdziemy nihilistycznego śmiechu, lecz wiedzę o człowieku, o mechanizmach zbrodni, o „fenomenologii obozu" ${ }^{\prime 36}$.

Brycht w Zmiennej ogniskowej nie jest pisarzem, lecz (miernym) publicystą. To historia więźnia (Auschwitz?) księdza Leona Gerbera, którego bohaterski czyn - oddanie życia za współtowarzysza niedoli - stanowi przedmiot ogólnego uznania i podziwu. Jego wyrazem jest budowa pomnika upamiętniającego heroizm Gerbera. Analogie z ojcem Maksymilianem Kolbe są łatwo rozpoznawalne. Wprawdzie Brycht na stronie przytytułowej zastrzega: „Książka ta jest w całości utworem fikcyjnym. Podobieństwo do sytuacji rzeczywistych jest przypadkowe. Podobieństwo charakterów w niej występujących do osób żywych lub zmarłych jest niezamierzone" ${ }^{37}$, jednak zarazem czyni wiele, by te skojarzenia podtrzymać. Tak więc Antoni Gil ma cechy Franciszka Gajowniczka ocalonego przed śmiercią przez Kerbera/Kolbego.

Zmienna ogniskowa to diatryba na chrześcijaństwo i jego duchowych przywódców - kler. Cel ataku - Kerber - został dokładnie zdefiniowany i obnażony. Głównym przedmiotem idiosynkrazji narratora jest zresztą nie tyle Kerber/ Kolbe, co samo duchowieństwo. Ostrość tych wypowiedzi zaniepokoiła nawet cenzora, który zdecydował się usunąć passus z kwestii Gila:

\footnotetext{
${ }^{36}$ Odwołuję się do tytułu jednego z rozdziałów książki Andrzeja Wernera. Zob. A. Werner, Fenomenologia obozu, w: Zwyczajna apokalipsa. Tadeusz Borowski i jego wizja świata obozów, Czytelnik, Warszawa 1971.

${ }^{37}$ A. Brycht, Zmienna ogniskowa, w: Opowieści z tranzytu, Wydawnictwo Łódzkie, Łódź 1986.
} 
- Chciał tych najgorszych skurwysynów zobaczyć z bliska. Tych wypasionych karmazynów, biskupów, spekulantów, bogaczy, tego [Ustawa z dn. 31 VII 81 r., O kontroli publikacji i widowisk, art. 2, pkt. 8 (Dz.U. nr 20, poz. 99, zm.: 1983 r. Dz.U. nr 44, poz. 204 i z 1984 r. nr 5, poz. 24)]. Musiał ich zobaczyć, żeby wiedzieć, kogo nienawidzi. Zobaczył Kościół, który błogosławił armie morderców, a teraz sprytnie godzi mordercę z mordowanym, dla zysku ${ }^{38}$.

Znając metodę twórczą Brychta - w której bunt oraz prowokacja były często wykorzystywanym środkiem ekspresji - można powiedzieć, że Zmienna ogniskowa stanowi jedynie kolejne ogniwo w łańcuchu. A jednak trudno nie zauważyć różnicy między pierwszymi ogniwami łańcucha a ostatnimi. Prowokacja wczesnych opowiadań miała swój cel, uderzała w schematy obyczajowe, stereotypy $\mathrm{w}$ widzeniu świata, w dobre samopoczucie odbiorcy. W Zmiennej ogniskowej jej ostrze skierowane jest w próżnię.

Dlaczego Brycht zdecydował się napisać zajadłą, zakłamaną opowieść o losach księdza Kolbego? Być może - przebywając od 1971 roku na emigracji - nie znał realiów Polski lat 80., nie wiedział, że społeczeństwo żyje innymi problemami. Nie wiedząc tego, mógł liczyć na finansowy tryumf, na przypomnienie o sobie jako demistyfikatorze, w którym wciąż tli się pasja protestu i wolny duch. Taka interpretacja pozwalałaby widzieć Zmienna ogniskowa jako pierwszy odcinek drogi, na której wypada umieścić również Azyl polityczny i Sandrę. Na poły pornograficzna Sandra i bałamutny (zakłamany) Azyl polityczny były rozpaczliwą (ostatnią) próbą zyskania rozgłosu w rzeczywistości rodzącego się kapitalizmu. Miały stanowić powrót do lat 60 ., kiedy warszawska ulica deklamowała: „Brycht, Brycht i więcej nicht”. Jednak było to niemożliwe, tyleż za sprawą

${ }^{38}$ Tamże, s. 68. W Słowach z chaosu Brycht podkreśla wielokrotnie opresyjną rolę cenzury wobec swoich tekstów (zob. tenże, Słowa z chaosu, „Kultura” 1971, nr 9). Czytając bowiem wypowiedź zamieszczoną na łamach paryskiej „Kultury”, odnosi się wrażenie, iż Brychta uwierały przede wszystkim działania Głównego Urzędu Kontroli Publikacji i Widowisk. Z twórcy, którego raport o Niemczech lat 60 . dodrukowywano na polecenie Gomułki, staje się on jedną z ofiar systemu tłamszącego wolność słowa. Jest to z pewnością kwestia wymagająca odrębnych badań. Nie ulega bowiem wątpliwości, że tekstów autora Suchych traw nie ominęło cenzorskie oko. Chojnowski poczynił następującą uwagę: „We wczesnych utworach (m.in. Czerwony węgiel, wydanie książkowe 1960) Brycht opisywał katorżniczy los zesłanych do kopalni, okrucieństwo żołnierzy Korpusu Bezpieczeństwa Wewnętrznego, sadystyczne relacje między skazańcami a personelem więziennym itp. Odmalowany przez niego obraz ludzkiego upodlenia przerażał intensywnością, toteż cenzura usunęła co bardziej drastyczne sceny" (A. Chojnowski, dz. cyt., s. 118). Dokładne określenie skali ingerencji cenzury w utwory Brychta obecnie jest tylko do pewnego stopnia rozpoznana. Należałoby przeprowadzić dokładna kwerendę pośród materiałów zgromadzonych w archiwach GUKPPiW. Podobnie wszakże jak w przypadku innych rodzajów piśmiennictwa, najtrudniejsze do wykrycia są mechanizmy autocenzury (zob. K. Budrowska, Literatura i pisarze wobec cenzury PRL 1948-1958, Wydawnictwo Uniwersytetu w Białystoku, 2009). A jak wychwycić wpływ „czynników partyjnych”, nieformalnych nacisków, sugestii? 
nowych czasów, co samego autora. Sandra i Azyl polityczny nie mają nic wspólnego $\mathrm{z}$ duchem autentyzmu konstytuującym wczesną prozę Brychta. A bez niego jest o jeden powód mniej, by wracać do Brychta.

Za Raportem z Monachium stały między innymi racje czysto pragmatyczne. Za Azylem politycznym oraz Sandra już tylko resentymenty i ukryte kompleksy. Pierwsza z tych książek bywa jeszcze łączona z nazwiskiem Brychta, druga - sygnowana łatwym do rozszy frowania pseudonimem Andrew Bright - już nie. Czym są te dwa utwory? Z pewnością świadectwem pisarskiej agonii i wściekłości. Brycht często prowokował, wymierzał cios prosty w szczękę - często zresztą niecelnie. W Azylu politycznym jednak bije na oślep. Nie ma już celu, tam gdzie celem jest wszystko wokoło; gdzie idiosynkrazja staje się zasadą kierującą ludzkimi myślami i uczuciami:

Styl, jakim tę książkę napisał, powoduje, że wymyka się ona wszelkim próbom opisu. Jej przesłaniem była uniwersalna nienawiść do wszystkich spotkanych przez Brychta ludzi, a metodą literacką - rynsztokowa inwektywa. [...] Wulgarna, prostacka, pornograficzna i antysemicka, w jednaki sposób lżyła Polaków i Żydów, katolików i homoseksualistów, uciekinierów od komunizmu i komunistów, Belgów i Amerykanów, Jerzego Giedroycia i Gustawa Herlinga-Grudzińskiego, Stefana Kisielewskiego i Czesława Miłosza. Jedyną pozytywną postacią książki, wszechmądrą, zdrową psychicznie i fizycznie, ferującą wyroki i oceny ludzi, oceny zdarzeń i systemów, był sam Brycht ${ }^{39}$.

Być może szaleństwo Azylu politycznego i Sandry wynikało z psychologicznej pułapki, w jaką wpadł autor. Wkraczamy na grząski teren rozważań o psychice artysty. Brycht mógł mieć żal do samego siebie. Pobyt na Zachodzie i wyjazd do Kanady, w której ani nie zrobił kariery literackiej, ani nie zarobił pieniędzy, okazał się porażką. Nie miał już swoich polskich czytelników. Rozpoczynał i marzył o kolejnych projektach wydawniczych, ale ich nie kończył albo miał zbyt wielkie oczekiwania, nadzieje z nimi związane, ale żadna z nich się nie spełniała. To musiało rodzić poczucie klęski, nawet (a może zwłaszcza) w kimś tak ambitnym, jak Brycht. Ze zwycięzcy i zdobywcy, jakim chciał być (i jakim był w latach 60.) stał się nieudacznikiem. Od 1971 roku autor Opadania ziemi, on wolny duch, król życia musiał liczyć już nie tylko na siebie, ale też na innych. Decyzja o emigracji - patrząc z pozycji wielkopańskiego stylu życia, od którego uciekł - okazała się pomyłką. Być może więc to Brycht był swoim największym wrogiem - człowiek rozżalony i zawiedziony. Literatura zaś stała się świadkiem i przekaźnikiem dla jego stanu ducha.

Zatem, patrząc holistycznie na twórczość Brychta, widzimy, że momentem przełomowym - początkiem literackiego upadku - jest Raport z Monachium. Od

\footnotetext{
${ }^{39}$ H. Dasko, dz. cyt., s. 96.
} 
tego czasu jest coraz gorzej. Pojawia się destruktywna i paraliżująca gorycz. Teksty powstałe po Raporcie z Monachium mają umocowanie już nie w rzeczywistości, a w żółci trawiącej wnętrze pisarza. Jeśli siłą powieści i opowiadań Brychta był zaszczepiony w nich bakcyl buntu, to totalny sprzeciw wymierzony we wszystko dookoła w przypadku dzieł dojrzałego już pisarza (w momencie powstania Azylu politycznego i Sandry skończył on pięćdziesiąt lat) musiał budzić irytację u czytelników. Wszak nie był to już młodzieńczy sprzeciw z Suchych traw, Opadania ziemi czy Ulicy Pomarańczowej. Po trzydziestu latach pasja i niekłamany głos protestu znany z wczesnych tekstów nie tylko nie miały już tej siły rażenia, ale wydawały się anachroniczne, nieprawdziwe, sztuczne. Dowodziły raczej - w najlepszym wypadku - intelektualnego infantylizmu, emocjonalnej niedojrzałości, a w innym - manii i obsesji, sprzyjania najniższym instynktom psychice jednostki. Nie potrafimy już uwierzyć narratorowi Azylu politycznego: „Pisać trzeba o wszystkim, i to całą prawdę, z grubej rury, choćby była nie wiem jak nieapetyczna”40. Prawda nie tylko nie jest niepatetyczna - u Brychta próżno zresztą takiej szukać - ale nie jest już prawdą. To zbiór pomówień, insynuacji, sensacji i banalnych teorii na temat natury emigracji, polityki, polskości, duszy artysty.

\section{Dlaczego wracać do Brychta?}

Powtórzmy pytanie zadane na początku: Po co wracać do Brychta - osoby o takiej kondycji moralnej i takiej biografii? Odpowiedź emocjonalna może brzmieć tak: ludzie o podobnych życiorysach, odszczepieńcy, prowokatorzy, a nawet cynicy często przyciągają naszą uwagę. Sięga się po te postaci, by szukać sensacji, podniecających opowieści, intrygujących anegdot. Takie natury jak Brycht zdają się być tyglem dowolnie ułożonych elementów. Zazwyczaj szukamy w świecie porządku. Entropia budzi w nas nieufność, a nawet przeraża. Stąd pokusa, by zajrzeć do duszy takich ludzi jak Brycht - przejrzeć ją, prześwietlić, przeprowadzić wiwisekcję. Autor Suchych traw przecież ucieleśniał mit chuligana. Agresywny, skory do bójki, były bokser, lubił żyć „,na pełnym gazie”. Do tego dochodziły jego dwie wielkie namiętności - oprócz samochodów i pieniędzy - kobiety i alkohol. Zwłaszcza jednak kobiety. Również kulisy jego współpracy SB oraz decyzja o pozostaniu na Zachodzie budzą ciekawość z racji swej enigmatyczności i zagadkowości ${ }^{41}$.

\footnotetext{
${ }^{40}$ A. Brycht, Azyl polityczny, Krajowa Agencja Wydawnicza, Łódź 1989, s. 188.

${ }^{41}$ Geneza decyzji pisarz z końca czerwca 1971 roku we włoskiej miejscowości La Spezia, aby pozostać na Zachodzie, jest ciągle tajemnicą. Najprawdopodobniej znaczną rolę odegrała tu chęć wyjazdu na Zachód (A. Chojnowski, dz. cyt., s. 125). Czy pomogła w jej podjęciu piękna wybranka, studentka warszawskiej ASP, Aleksandra Gaganaszwili? Czy może to nieokiełzana natura,
} 
Jeśli wszakże zostawić na boku nimb prowokującego, nieokiełzanego artysty, szalonej duszy, co pozostanie? Po pierwsze, gdy przestają nas oburzać i fascynować obyczajowe ekscesy pisarza, rodzi się refleksja, że w równym stopniu osoba i dzieło Brychta mogą stanowić ciekawy asumpt do opowieści o PRL - realiach społeczno-obyczajowych, relacjach ówczesnych elit artystycznych z władzą, ale też studium o meandrach ludzkiej psychiki ${ }^{42}$. Niezwykłe wolty ideowe, jakich dokonywał Brycht, budzą zaciekawienie, każą stawiać pytanie o genezę wyborów etycznych, jakich dokonywali rodzimi poeci i prozaicy w epoce gomułkowskiej i później. Zatem portret Brychta byłby tyleż portretem jego jako twórcy, co czasów, w których żył.

Po drugie, teksty, które wyszły spod pióra Brychta do momentu publikacji Raportu z Monachium, stanowią przykład prozy wysokiej próby. Na tle choćby Moniki Kotowskiej, Aleksandra Minkowskiego, Magdy Lei - przedstawicieli pokolenia '56 - bohaterowie Brychta i problemy, przed jakimi stają - tak jak bohaterowie Marka Nowakowskiego, Jana Himilsbacha albo Janusza Krasińskiego - kryją w sobie rys autentyczności, potwierdzony biografią artysty. Dlatego też Nowakowski, Himilsbach, Krasiński i Brycht, choć osobowościowo sytuowali się na różnych biegunach, mogli mieć poczucie wspólnoty, przekonanie, że pochodzą jakby ze świata, o którym inni ich koledzy opowiadają w swoich tekstach, a który oni dobrze znają z własnego doświadczenia.

Opowiadania Brychta stanowią modelowy przykład lakoniczności stylu, kondensacji treści. Jacek Trznadel tę cechę literackiego warsztatu dostrzegł, recenzując debiutancki tom pt. Czas bez Marii. Krytyk mówił o wierszach Brychta: „Są skomponowane bezbłędnie, nie ma w nich zbędnych epizodów, opisów, dialogów, słów. Są oszczędne i bardzo precyzyjne"43. Taka jest też proza z najlepszego dla niej czasu, gdy duchowa niezależność jej twórcy skutkowała tekstami ze sfery „życiopisania”. Po latach Nowakowski odnotuje: „Miał nieomylne wyczucie słowa, kilka mu starczyło, żeby zbudować obraz" ${ }^{44}$.

Brycht był mistrzem krótkiej formy. Doskonale korespondowała ona $\mathrm{z}$ jego impulsywnym charakterem, ale też z jego predylekcją do zwięzłych, krótkich

emocjonalna niestabilność Brychta i tym razem nie pozwalała o sobie zapomnieć. Chojnowski przypomina sprawy znane: „Obiektywnie biorąc, Brycht nie miał [...] powodów do desperackich kroków Tym większe były niepokoje Służby Bezpieczeństwa, która obawiała się, że decyzja pisarza odzwierciedla jego emocjonalną niestabilność, popychającą go w stronę zachowań ekstremalnych" (tenże, dz. cyt., s. 131). A może wybór emigracji stanowi tygiel kilku zmiennych: nalegań Gaganaszwili na wyjazd oraz przekory i buntowniczego ducha Brychta. Dlaczego też nie wierzyć w to, że wolnościowe i anarchistyczne serce autora Balbiny dosięgła frustracja spowodowana współpracą ze Służbą Bezpieczeństwa.

42 Monografię twórczości Brychta przygotowuje na Uniwersytecie Kardynała Stefana Wyszyńskiego Joanna Gzyra.

43 J. Trznadel, Bezpośredniość między konwencjami, „Twórczość” 1962, nr 7, s. 120.

${ }^{44}$ M. Nowakowski, Pióro..., s. 40. 
charakterystyk postaci. Wyraziści bohaterowie prozy Brychta wydobyci z ich naturalnego środowiska - peryferii życia społecznego - z trudnością odnaleźliby się na kartach nobliwej powieści. Powieść bowiem przerastała autora Suchych traw. Jak dla większości przedstawicieli generacji '56 - także tych „tragicznych i przeklętych" - opowiadanie i nowela okazywały się kompatybilne z niespokojnym duchem pisarza i jego czasów.

Powieść - zwłaszcza ta znana XIX-wiecznej tradycji realistycznej - wymaga zazwyczaj dystansu do przedmiotu opisu, czasu i innej formy pracy, w której trzeba znaleźć dłuższe chwile wyciszenia, potrzebne między innymi na lekturę, refleksję. Kolidowało to $\mathrm{z}$ temperamentem Brychta, jego nadpobudliwością emocjonalną. Jeszcze poważniejszą przeszkodą była jego niezdolność do syntezy, widzenia zjawisk z holistycznej perspektywy. Próby, które podejmował, kończyły się klęską. Świat dawał się wyjaśnić tylko na bazie teorii spiskowych. Jak już powiedziano, Brycht nie był intelektualistą. Nie tylko źle radził sobie z eksplikacjami mechanizmów, cywilizacyjnych, społecznych, historyczno-politycznych, ale też nie umiał osadzać i postrzegać opowiadanych historii na tle szerszym niż granica małej społeczności. Na tym obszarze był jednak mistrzem - niedościgłym obserwatorem i analitykiem.

* $\quad * \quad *$

Nie jest rolą badacza ocena wyborów moralnych artysty, ale może on już coś powiedzieć o „zmarnowanym talencie”. Gdzie upatrywać przyczyn literackiego upadku? Tak jak u poetów przeklętych nie da się odpowiedzieć na to pytanie, abstrahując od związku biografii i dzieła. Należy wskazać na co najmniej dwa problemy. Po pierwsze, źródła Brychtowego sukcesu biją w umiejętności czerpania z osobistego doświadczenia. Bezpośrednia znajomość zdarzeń i ludzi działała na niego jak afrodyzjak - pobudzała i napełniała energią. Wszystko, co zakłócało tę bezpośrednią więź, co ją skazywało na jakiekolwiek pośrednictwo, okazywało się zabójcze dla tej prozy. W pewnym momencie w taką przesłoną stało się zaangażowanie w politykę i współpracę ze służbami specjalnymi PRL. O ile z trudnością przyjmujemy deklarację Brychta, że w chwili powstawania Raportu $z$ Monachium był on „zielony politycznie jak arbuz" ${ }^{\text {,5 }}$, o tyle należy zgodzić się $z$ tezą, iż nie był intelektualistą. Nie był też odpowiednim materiałem na polityka. Ten musi bowiem często odłożyć na bok emocje. Brycht przy swojej umiejętności zdobywania pieniędzy, znalezienia się w odpowiednim miejscu i odpowiednim czasie, miał w sobie jeszcze jakieś resztki prostolinijności. Interpretacje zjawisk politycznych nie były zatem jego żywiołem. Widział je w prostackim uproszczeniu. Zapewne wierzył, że w zdrowym rozsądku zwykłego człowieka znajduje się

${ }^{45}$ A. Brycht, Slowa z chaosu, s. 11. 
klucz do rozwiązania dylematów kawiarnianej inteligencji (za którą nie przepadał). Kapitalizm - który w Raporcie z Monachium widział jako system nieudolny, wadliwy w zestawieniu z socjalizmem - w Kanadzie nie był w stanie dostarczyć mu inspiracji. Czy nie dlatego, że wymagał innego typu umysłu, wrażliwości?

O ile Brycht jakoś wyczuwał ukryty puls komunizmu - długo przecież udawało mu się układać z tym systemem, być kolorowym ptakiem w siermiężnej rzeczywistości towarzysza Wiesława - o tyle nie pojmował rodzącej się rzeczywistości po przełomie roku 1989. Kiedy powrócił do kraju, fundamenty peerelowskiej budowli kruszyły się w coraz szybszym tempie. Po 17 latach nieobecności czuł się nieco zagubiony. Przy tym nie chciał, a może i nie umiał, zdać sobie sprawy z tego, co się stało z literaturą polską począwszy od płowy lat 70. Co stało się z publicznością, która dwie dekady wcześniej tłumnie przybywała na jego spotkania autorskie. „Nie wiedział, że to on i inni «piękni dwudziestoletni» stali się ariergardą polskiego realizmu"46. Jak przekonuje Henryk Dasko, Brycht nie potrafił dostrzec sensu zmiany i przewartościowań na polu literatury. Nie rozumiał, że to poezja Stanisława Barańczaka, Adama Zagajewskiego, Juliana Kornhausera „stała się głosem artystycznego buntu i społecznego protestu, że zajęła miejsce kiedyś przynależne prozie jego pokolenia" " Dodajmy, iż w drugiej połowie lat 80. i w początkach kolejnej dekady na scenę wchodzą inni idole młodzieży - pokolenie „bruLionu”. Gusta i wybory czytelnicze zmieniają się szybko, tak, jak gwałtownie zmienia się rzeczywistość kulturowa. Dawni bohaterowie odchodzą w niepamięć. Dziś nazwisko Brycht nie mówi już wiele młodym ludziom.

\section{Bibliografia}

Andrzejewski Jerzy, Apelacja, Czytelnik, Warszawa 1983.

Błoński Jan, Brychta ballady podwórzowe, „Twórczość” 1968, nr 1, s. 114-116.

Brudnicki Jan Z., Stowo wstępne do: Kaskaderzy literatury, s. 7.

Brycht Andrzej, Azyl polityczny, Krajowa Agencja Wydawnicza, Łódź 1989.

Brycht Andrzej, Opadanie ziemi, Instytut Wydawniczy Pax, Łódź 1962.

Brycht Andrzej, Opowieści z tranzytu, Wydawnictwo Łódzkie, Łódź 1986.

Brycht Andrzej, Stowa z chaosu, „Kultura” 1971, nr 9, s. 3-14.

Budrowska Kamila, Literatura i pisarze wobec cenzury PRL 1948-1958, Wydawnictwo Uniwersytetu w Białymstoku, Białystok 2009.

${ }^{46}$ H. Dasko, dz. cyt., s. 90.

${ }^{47}$ Tamże, s. 90. Dasko buduje nazbyt uproszczony obraz lat 80., w których oprócz poezji Nowej Fali, istniała poezja i piosenka antykomunistycznych bardów, a oficyny działające w podziemiu wprowadzały coraz większą liczbę dzieł literackich, filozoficznych, historiograficznych, socjologicznych do czytelniczego obiegu. A przecież istniała jeszcze - na innych zasadach i z innymi prerogatywami artystycznymi - prężnie rozwijająca się od lat 70. proza lingwistyczna. Zob. najpoważniejsze opracowanie na temat prozy lingwistycznej: J. Galant, Polska proza lingwistyczna. Debiuty lat siedemdziesiatych, Wydawnictwo Naukowe UAM, Poznań 1998. 
Chojnowski Andrzej, Sceny ukryte z życia pisarza. Tajemnice Andrzeja Brychta, „Dzieje Najnowsze" 2008, nr 3, s. 117-133.

Dasko Henryk, Odlot malowanego ptaka, wybór tekstów i koncepcja książki Michał Komar, Rosner i Wspólnicy, Warszawa 2009.

Drewnowski Tadeusz, Krytyka i giełda. Szkice literackie, Czytelnik, Warszawa 1969.

Galant Jan, Polska proza lingwistyczna. Debiuty lat siedemdziesiątych, Poznańskie Studia Filologiczne. Seria Literacka, Wydawnictwo Naukowe UAM, Poznań 1998.

Kaskaderzy literatury. O twórczości i legendzie Andrzeja Bursy, Marka Hłaski, Haliny Poświatowskiej, Edwarda Stachury, Ryszarda Milczewskiego-Bruna, Rafała Wojaczka, pod red. Edwarda Kolbusa, słowo wstępne Jan Z. Brudnicki, posł. Jan Marx, wyd. 2, Łódź 1990.

Krzyżanowski Jerzy R., O pisarstwie Andrzeja Brychta, „Kultura” 1967, nr 3, s. 135-138.

Kuncewicz Piotr, Agonia i nadzieja, T 4: Proza polska od 1956, Graf-Punkt; Polska Oficyna Wydawnicza „BGW”, Warszawa 1994.

Lisiecka Alicja, Prognoza pogody, Czytelnik, Warszawa 1966.

Łysak Tomasz, Jakiej historii potrzeba? Tematyka obozowa w zapomnianych tekstach Andrzeja Brychta i Tadeusza Hotuja, „Kwartalnik Filmowy” 2012, nr 77/78, s. 168-184.

Nowakowski Marek, Pióro. Autobiografia literacka, Iskry, Warszawa 2012.

Nowakowski Tadeusz, Manneken-pis, „Kultura” 1967, nr 6, s. 124-142.

Orski Mieczysław, Etos lumpa. Szkice literackie, Zakład Narodowy im. Ossolińskich, Wrocław 1978.

Polniak Łukasz, Patriotyzm wojskowy w PRL w latach 1956-1970, Wydawnictwo Trio, Warszawa 2011. Szewczyk Wilhelm, Podróż w kręgi piekielne, „Miesięcznik Literacki” 1968, nr 2, s. 114-116.

Trznadel Jacek, Bezpośredniość między konwencjami, „Twórczość” 1962, nr 7, s. 118-121.

Werner Andrzej, Zwyczajna apokalipsa. Tadeusz Borowski i jego wizja świata obozów, Czytelnik, Warszawa 1971.

Zaremba Marcin, Komunizm, legitymizacja, nacjonalizm. Nacjonalistyczna legitymizacja władzy komunistycznej w Polsce, Wydawnictwo Trio, Warszawa 2001.

Sławomir Buryła

\section{Report of cynic? Andrzej Brycht and his body of work}

\section{(Summary)}

The author of this paper discusses the prose of Andrzej Brycht, comparing it with the writer's biography and the collective biography and works of the "Współczesność" generation. The article presents and documents the uniqueness of Brycht's early short stories in the context of his style and skill in building expressive literary characters. This paper closes with an attempt to give the reasons for the writer's artistic failure.

Keywords: Realistic prose, writer's biography, artistic evolution 